\title{
INTERACTION BETWEEN GELATIN AND NANO-SILVER PARTICLE: FOUNDATION FOR NANO-SILVER IN ANTIBACTERIAL LEATHER
}

\author{
Jinwei ZHANG ${ }^{1,2}$, Weite YANG ${ }^{1}$, Yonghan WEN ${ }^{3}$, Hongbin SUN ${ }^{4}$, Guojun $\mathrm{ZHU}^{3}$, Wuyong $\mathrm{CHEN}^{1^{*}}$ \\ ${ }^{1}$ Key Laboratory of Leather Chemistry and Engineering of the Ministry of Education, Sichuan University, \\ Chengdu, 610065, P.R. China \\ ${ }^{2}$ Research institutes of leather and footwear industry of Wenzhou, Wenzhou, 325000, P. R. China \\ ${ }^{3}$ Guangdong Jiangmen Supervision Testing Institute of Quality and Metrology, Jiangmen 529000, P. R. China \\ ${ }^{4}$ Guangdong Shengfang Chemical Corporation, Jiangmen 529162, P. R. China
}

Received: 18.10 .2020

Accepted: 10.03.2021

https://doi.org/10.24264/Ifj.21.1.4

INTERACTION BETWEEN GELATIN AND NANO-SILVER PARTICLE: FOUNDATION FOR NANO-SILVER IN ANTIBACTERIAL LEATHER

ABSTRACT. In order to explain the interaction between collagen and nano-silver, gelatin solution was blended with nano-silver particles (AgNPs) with particle size $26 \mathrm{~mm}$, and then the mixture was interacted under different time, $\mathrm{pH}$ and temperature. The changes in the process were measured by UV-Vis, fluorescence spectroscopy, dynamic light scattering and FT-IR. The results showed that the main type of reaction between gelatin and AgNPs was electrostatic interaction and the interaction was diffusive encounters. The particle size and distribution of nano-silver would not be affected by gelatin, however, there was dynamic fluorescence quenching of gelatin after nano-silver particle induced. The longer time and lower $\mathrm{pH}$ were beneficial for the interaction process while the interaction balanced after $60 \mathrm{~min}$ and $\mathrm{pH} 3.0$ resulted in the most drastic interaction. Moreover, nano-silver would not impair gelatin structure during the interaction process. In short, the results in this work might be a foundation and reference for applying nano-silver in antibacterial leather producing.

KEY WORDS: gelatin, nano-silver, interaction process

INTERACȚIUNEA DINTRE GELATINĂ ȘI NANOPARTICULE DE ARGINT: FUNDAMENTUL UTILIZĂRII NANOPARTICULELOR DE ARGINT PENTRU A OBȚINE PIELE CU PROPRIETĂȚI ANTIBACTERIENE

REZUMAT. Pentru a explica interacțiunea dintre colagen și nanoparticule de argint, soluția de gelatină a fost amestecată cu nanoparticule de argint (AgNP) cu dimensiunea particulelor de $26 \mathrm{~mm}$, iar apoi amestecul a fost supus unor interacțiuni în condiții diferite de timp, $\mathrm{pH}$ și temperatură. Modificările procesului au fost măsurate prin UV-Vis, spectroscopie de fluorescență, împrăștiere dinamică a luminii și FT-IR. Rezultatele au arătat că principalul tip de reacție dintre gelatină și AgNP a fost interacțiunea electrostatică prin difuzie. Dimensiunea particulei și distribuția nanoparticulele de argint nu au fost afectate de gelatină, cu toate acestea, a existat stingerea dinamică a fluorescenței gelatinei după inducerea nanoparticulelor de argint. Timpul mai lung și pH-ul mai scăzut au fost benefice pentru procesul de interacțiune, în timp ce interacțiunea s-a echilibrat după 60 de minute, iar pH-ul de 3.0 a dus la cea mai drastică interacțiune. Mai mult, nanoparticulele de argint nu afectează structura gelatinei în timpul procesului de interacțiune. Pe scurt, rezultatele acestei lucrări ar putea constitui un fundament și o referință pentru aplicarea nanoparticulelor de argint în obținerea pielii cu proprietăți antibacteriene.

CUVINTE CHEIE: gelatină, nanoparticule de argint, proces de interacțiune

\section{L'INTERACTION ENTRE LA GÉLATINE ET LES NANOPARTICULES D'ARGENT : LES FONDAMENTAUX DE L'UTILISATION DE NANOPARTICULES D'ARGENT POUR OBTENIR UNE PEAU AUX PROPRIÉTÉS ANTIBACTÉRIENNES}

RÉSUMÉ. Pour expliquer l'interaction entre le collagène et les nanoparticules d'argent, la solution de gélatine a été mélangée avec des nanoparticules d'argent (AgNP) d'une taille de particule de $26 \mathrm{~mm}$, puis le mélange a été soumis à des interactions dans différentes conditions de temps, de $\mathrm{pH}$ et de température. Les changements de processus ont été mesurés par UV-Vis, spectroscopie de fluorescence, diffusion dynamique de la lumière et FT-IR. Les résultats ont montré que le principal type de réaction entre la gélatine et les AgNP a été l'interaction électrostatique par diffusion. La taille des particules et la distribution des nanoparticules d'argent n'ont pas été affectées par la gélatine, cependant, il y avait une extinction dynamique de la fluorescence de la gélatine après l'induction de nanoparticules d'argent. Un temps plus long et un $\mathrm{pH}$ plus bas ont été bénéfiques pour le processus d'interaction, tandis que l'interaction a été équilibrée après 60 minutes, et un $\mathrm{pH}$ de 3,0 a conduit à l'interaction la plus drastique. De plus, les nanoparticules d'argent n'affectent pas la structure de la gélatine pendant le processus d'interaction. En bref, les résultats de ce travail pourraient être une base et une référence pour l'application de nanoparticules d'argent envers d'obtenir une peau aux propriétés antibactériennes.

MOTS CLÉS : gélatine, nanoparticules d'argent, processus d'interaction

\footnotetext{
" Correspondence to: Wuyong CHEN, Key Laboratory of Leather Chemistry and Engineering of the Ministry of Education, Sichuan University, Chengdu, 610065, P.R.China, wuyong.chen@163.com
} 


\section{INTRODUCTION}

Leather is a useful intermediate product with various applications in downstream industries like furniture, garment and footwear [1]. Footwear made from leather feels comfortable owing to its collagen interwoven structure and characters of breathability and softness [2]. However, leather is known to harbor bacterial growth due to its large surface area and richness in protein (collagen) that enhance bacterial reproduction by providing space and nutrients [3]. Especially, ideal moisture and temperature for bacterial reproduction will be emerged in shoes under the circumstance that sweat from foot skin is absorbed by leather [4]. The large scale of microbial reproduction on leather will not only cause unpleasant odor but also may bring numerous infectious diseases [57]. Therefore, antibacterial leather is urgent and necessary for upgrading leather goods quality and generating better experience for customer. Antibiotics can be used to inhibit bacterial growth on leather, but drug-resistant bacteria and compatibility may become a big challenge and obstacle $[8,9]$.

Silver nanoparticles (AgNPs) are an excellent antibacterial agent with broadspectrum antimicrobial property and low toxicity $[10,11]$. AgNPs have been widely investigated and applied to improve antimicrobial activity of leather by coating or soaking $[12,13]$. The AgNPs with particle size of $26 \mathrm{~nm}$ was prepared by using sodium borohydride as reductant and benzalkonium bromide as protective agent [14], and this kind of AgNPs was used for producing antibacterial sheepskin [15] and antibacterial leathers $[16,17]$. In order to realize the process of making antibacterial fur with AgNPs and help optimize technology parameters, the theoretical research on interaction between keratin and AgNPs was carried out [18]. No matter what kinds of procedures are used to apply nanosilver in antibacterial leather making, the interaction between collagen and AgNPs is essential. Nevertheless, there are few studies on interaction between collagen and AgNPs [19], consequently, antibacterial leather producing with AgNPs was still based on empirical rule rather than scientific foundation.

Collagen could be used for studying the influence of AgNPs on leather structure [20].
However, collagen is thermal sensitive, thus the temperature in the study would be too narrow in order to avoid collagen denaturing [21]. Gelatin is a collagen hydrolysate with almost the same component and structure excluding triple helix structure [22]. Therefore, gelatin could mimic collagen for carrying out reactions under wide temperature and other extreme conditions. Hitherto, the studies on interaction between collagen or gelatin and nano-silver focused on using protein in AgNPs synthesis [23, 24]. Some researchers also paid attention to applying AgNPs for preparing gelatin based antibacterial hydrogel $[25,26]$. But the interaction between prepared AgNPs and gelatin in solution to clarify the regulation of the process had not been studied yet. In this work, the gelatin as mimics of collagen was interacted with AgNPs under different time, $\mathrm{pH}$ and temperature. The changes in the process were measured by UVVis, fluorescence spectroscopy, dynamic light scattering and FT-IR. The results could provide foundation and reference for antibacterial leather with nano-silver.

\section{EXPERIMENTAL}

\section{Materials}

Silver nitrate, sodium borohydride, hydrochloric acid and sodium hydroxide were research grade chemicals from Chengdu Kelong Chemical Ltd. Benzalkonium bromide solution ( $5 \% \mathrm{w} / \mathrm{w})$ was bought from Nanchang Baiyun Pharmaceutical Co., Ltd. Type B gelatin with molecular weight about $100 \mathrm{kDa}$ was purchased from Sigma-Aldrich. Other reagents in the research were research grade.

\section{Sample Preparations}

\section{Nano-silver Particle (AgNPs) Preparation}

$0.015 \mathrm{~g}$ silver nitrate was dissolved in $100 \mathrm{~mL}$ distilled water and warmed by DF-101S water bath heater (Wuhan Ke'er instrument Company) at $30^{\circ} \mathrm{C}$ for $15 \mathrm{~min}$. $0.4 \mathrm{~g}$ benzalkonium bromide solution was blended with $100 \mathrm{~mL}$ distilled water and then added into silver nitrate solution with intense stirring for $30 \mathrm{~min}$ to form mixed 
solution. Subsequently, $200 \mathrm{~mL}$ solution containing 0.0074 sodium borohydride and $0.8 \mathrm{~g}$ benzalkonium bromide solution was dropped into the mixed solution with intense stirring for $1.5 \mathrm{~h}$ to obtain silver nano-silver particle (AgNPs). Particle size of the AgNPs was $26 \mathrm{~mm}$ and silver concentration was $0.024 \mathrm{~g} / \mathrm{L}$ or $8.25 \times 10^{-11} \mathrm{~mol} / \mathrm{L}^{14}$

Interaction between Gelatin and Nano-silver Particles under Different $\mathrm{pH}$

$20 \mathrm{~mL}$ gelatin solution with concentration $1 \mathrm{~g} / \mathrm{L}$ was mixed with $20 \mathrm{~mL}$ AgNPs solution with particle size of $26 \mathrm{~nm}$; then $0.01 \mathrm{~mol} / \mathrm{L}$ hydrochloric acid or 0.01 $\mathrm{mol} / \mathrm{L}$ sodium hydroxide was used to adjust the $\mathrm{pH}$ of each mixed solution to 2.0, 3.0, 4.0, 5.0, 6.0, 7.0, 8.0, 9.0 and 10.0; finally, the solutions were stirred at $30^{\circ} \mathrm{C}$ for 120 $\min$.

Interaction between Gelatin and Nano-silver Particles under Different Time

$20 \mathrm{~mL}$ gelatin solution with concentration $1 \mathrm{~g} / \mathrm{L}$ was mixed with $20 \mathrm{~mL}$ AgNPs solution with particle size of $26 \mathrm{~nm}$; then the solutions were stirred at $30^{\circ} \mathrm{C}$ for $0.5,6,15,30,60$ and $120 \mathrm{~min}$.

Interaction between Gelatin and Nano-silver Particles under Different Temperature

Gelatin solution was blended with different AgNPs and the gelatin-AgNPs solutions with silver concentration $0,8 \times 10^{-}$ $12,1.6 \times 10^{-11}, 2.4 \times 10^{-11}, 3.2 \times 10^{-11}$ and $4 \times 10^{-11}$ $\mathrm{mol} / \mathrm{L}$ were prepared. The gelatin-AgNPs solutions were stirred at 20,30 and $40^{\circ} \mathrm{C}$ for $60 \mathrm{~min}$.

\section{Testing Methods}

\section{UV-Vis Measurement}

Lambda 25 UV-Vis spectrometer (Perkin Elmer, America) was used to measure gelatin-AgNPs solution at $25^{\circ} \mathrm{C}$ with wavelength from 200 to $800 \mathrm{~nm}$ and scanning rate $240 \mathrm{~nm} / \mathrm{min}$.
Fluorescence Determination

The fluorescence emission spectra of gelatin-AgNPs solution were tested at $25^{\circ} \mathrm{C}$ or 20,30 and $40^{\circ} \mathrm{C}$ corresponding to the interactive temperature by using F-4010 fluorescence spectrometer (Hitachi, Japan). The excitation and emission wavelengths were $278 \mathrm{~nm}$ and $307 \mathrm{~nm}$; wavelength range was from 285 to $400 \mathrm{~nm}$; scan rate was 60 $\mathrm{nm} / \mathrm{min}$; excitation and emission slit widths was $5.0 \mathrm{~nm}$.

\section{Zeta Potential Test}

Zeta potential of gelatin-AgNPs solution was tested by Nano-ZS laser particle size analyzer (Malvern, UK). The solution was firstly filtered through $0.45 \mu \mathrm{m}$ microporous membrane and then transferred to a polystyrene cube for the measurement. All measurements were performed in triplicate and the solution was equilibrated for $5 \mathrm{~min}$ before the measurement at $25^{\circ} \mathrm{C}$.

\section{FT-IR Measurement}

The gelatin-AgNPs solution stirred at $30^{\circ} \mathrm{C}$ for $120 \mathrm{~min}$ was lyophilized, and the dried sample was ground with potassium bromide and made into thin sheets. Nicolet 10 FT-IR (Thermo Scientific Corporation, America) was used to scan in wavenumber range from 500 to $4000 \mathrm{~cm}^{-1}$ for 32 times, and the data was recorded. 


\section{RESULTS AND DISCUSSION}

Influence of Time on the Interaction between Gelatin and AgNPs

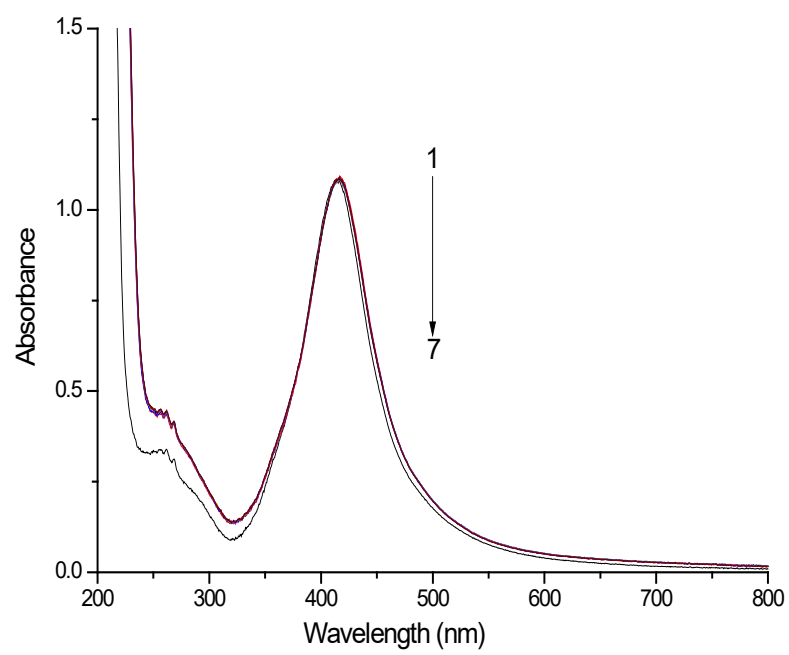

Figure 1. UV-vis spectra of gelatin-AgNPs solution interacted for different time ( 2 to 7 representing $0.5,6,15,30,60$ and 120 min interaction time respectively and 1 representing AgNPs)

The absorption peak of AgNPs usually locates at about $420 \mathrm{~nm}$ in UV-Vis spectrum and there is no peak of gelatin in the same place. Since AgNPs is a metastable system, it will be affected by environmental factor and result in UV-vis spectrum change. The peak intensity trends to weak and the peak width becomes wider when the stability of AgNPs is damaged [27]. As shown in Figure 1 , the peak intensity and width of gelatinAgNPs solutions were almost the same as solo AgNPs with interaction time increasing, indicating AgNPs particle size and distribution were not impacted by gelatin [28].

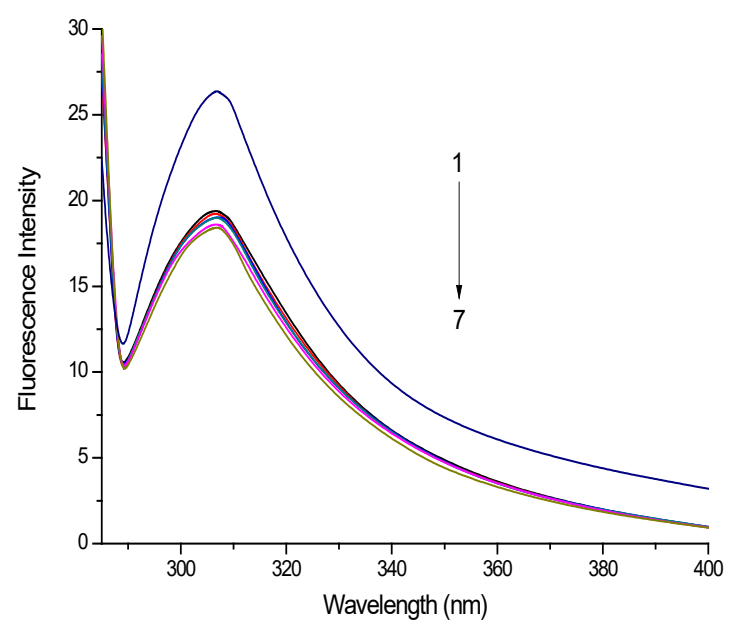

Figure 2. Fluorescence spectra of gelatin-AgNPs solution interacted for different time ( 2 to 7 representing $0.5,6,15,30,60$ and 120 min interaction time respectively and 1 representing gelatin) 


\begin{tabular}{ll}
\hline $\begin{array}{c}\text { Gelatin contains tyrosine and } \\
\text { phenylalanine but tyrosine content is }\end{array}$ & $\begin{array}{c}\text { balanced after } 60 \text { min. } \\
\text { Astherewasnochangein UV-Visspectra }\end{array}$ \\
more than 10 times than phenylalanine, & but fluorescence intensity decreasing, in \\
consequently, the intrinsic fluorescence & other words, structure of AgNPs remained \\
of gelatin mainly comes from tyrosine. & but gelatin conformation was affected. It \\
Protein structure transforming will change & could infer that the interaction was that \\
gelatin fluorescence intensity [29]. The & AgNPs was adsorbed on gelatin surface. This \\
fluorescence intensity of gelatin interacted & adsorption might alter spatial structure of \\
with AgNPs for different times was shown & gelation and led to fluorescence quenching. \\
in Figure 2. It was clear that AgNPs inducing & However, the adsorption interaction was \\
caused obvious fluorescence quenching and & too weak to impact AgNPs particle size and \\
fluorescence intensity of gelatin decreased & distribution.
\end{tabular}
with interaction time prolonging but nearly

\section{Influence of $\mathrm{pH}$ on the Interaction between Gelatin and AgNPs}

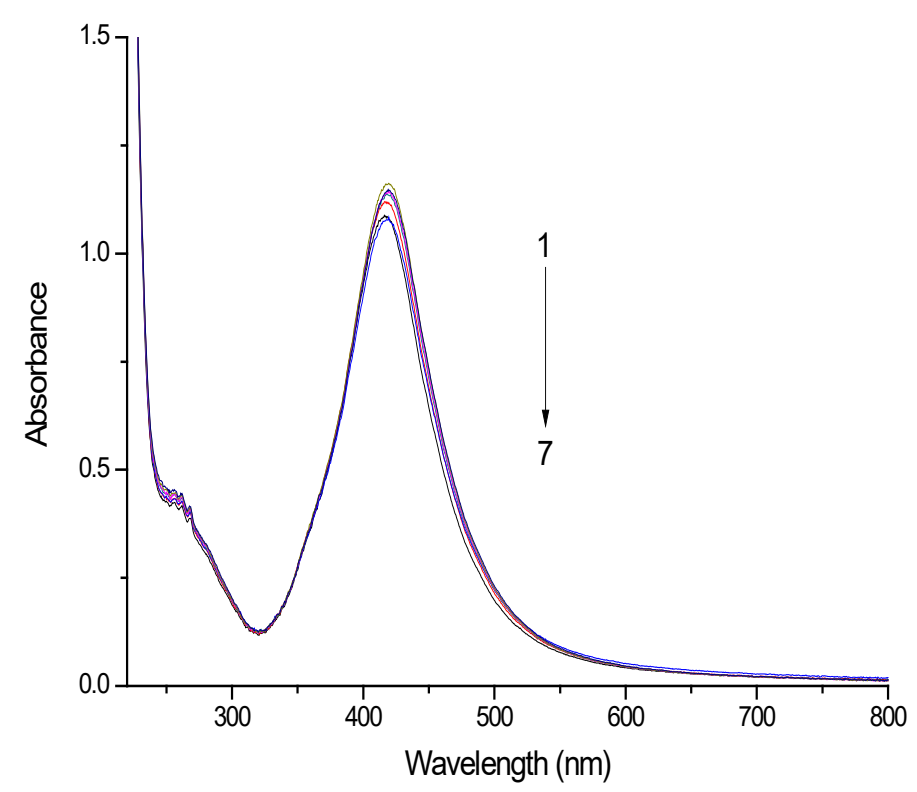

Figure 3. UV-vis spectra of gelatin-AgNPs solution interacted under different $\mathrm{pH}$ (1 to 7 representing $\mathrm{pH}$ values 9.0, 8.0, 7.0, 6.0, 5.0, 4.0, 3.0)

UV-vis spectra of gelatin-AgNPs solution interacted under different $\mathrm{pH}$ (Figure 3) showed lower $\mathrm{pH}$ benefited for the interaction between gelatin and AgNPs because smaller absorbance and violet shift was observed during interaction with $\mathrm{pH}$ reducing. 


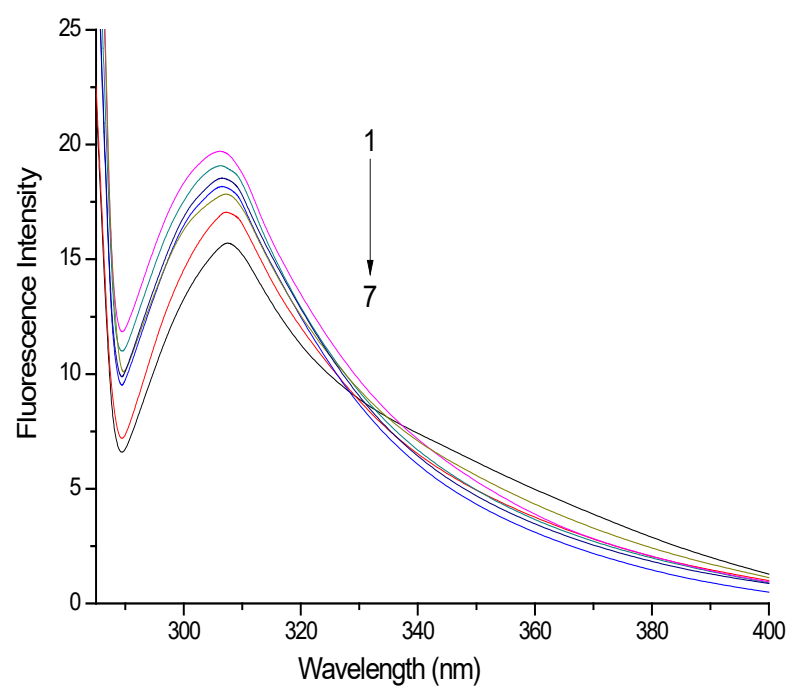

Figure 4. Fluorescence spectra of gelatin-AgNPs solution interacted under different $\mathrm{pH}$ (1 to 7 representing $\mathrm{pH}$ values 9.0, 8.0, 7.0, 6.0, 5.0, 4.0, 3.0)

Fluorescence intensity of gelatin more tyrosine residues were exposed to interacted with AgNPs under different $\mathrm{pH}$ was generate more intense fluorescence. Gelatin shown in Figure 4, and the results illustrated higher fluorescence intensity of gelatin was obtained under higher interaction $\mathrm{pH}$. The isoelectric point of gelatin used in the study was 9.6 based on experimental measurement, thus protein chain trended to unfolding under high $\mathrm{pH}$. Consequently, chains became folding with $\mathrm{pH}$ reducing and resulted in fluorescence intensity decreasing on one hand. On the other hand, gelatin folding with $\mathrm{pH}$ reducing might promote the absorption interaction and resulted in more tyrosine residues being hidden.

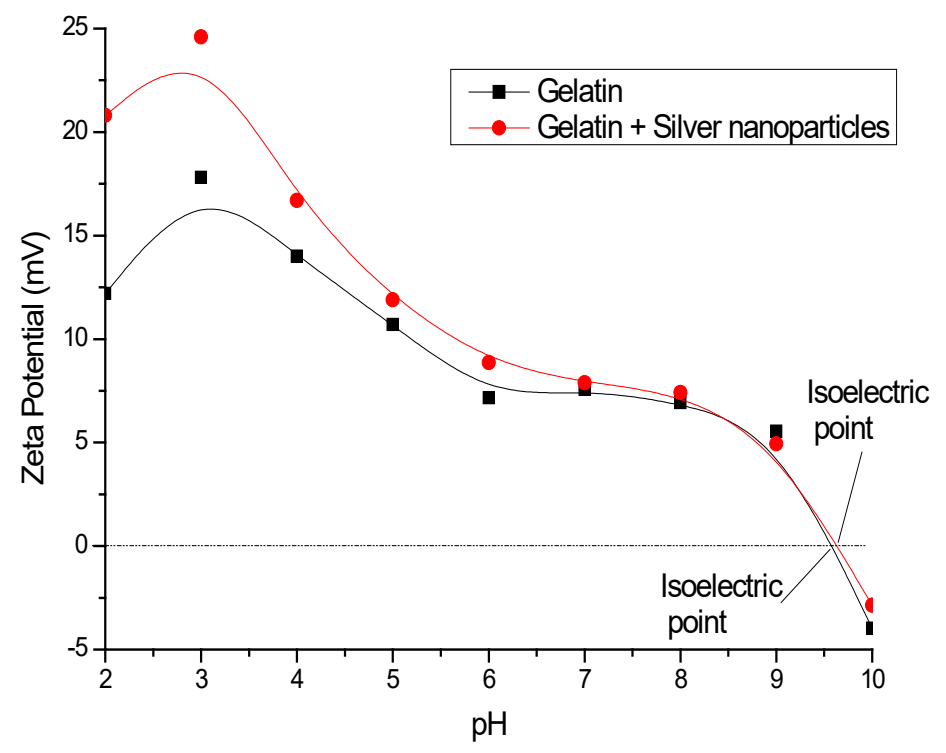

Figure 5. Zeta potential of gelatin-AgNPs solution interacted under different $\mathrm{pH}$ 
Figure 5 showed Zeta potential of gelatin-AgNPs solution interacted under different $\mathrm{pH}$. In Figure 5, there were two stages, the first one illustrated Zeta potential enlarged from $\mathrm{pH}$ range 2 to 3 , the second one demonstrated Zeta potential diminished with $\mathrm{pH}$ ascending from $\mathrm{pH}$ range 3 to 10 . Since Zeta potential of AgNPs was positive as cationic surfactant benzalkonium bromide was applied in the preparation procedure, the Zeta potential gelatin-AgNPs was larger than pure gelatin below isoelectric point as AgNPs was absorbed by gelatin. In addition, the differences of Zeta potential between gelatin-AgNPs solution and pure gelatin narrowed down with $\mathrm{pH}$ increasing, indicating lower $\mathrm{pH}$ facilitating the interaction process. However, much lower $\mathrm{pH}$ representing too hydrogen ion would impair colloidal electrical double layers and might have negative effect on system stability, thus the Zeta potential was maximum under $\mathrm{pH}$ 3.0.

Furthermore, the Zeta potential of pure gelatin was 0 when $\mathrm{pH}$ was 9.6 but it was 9.7 for gelatin-AgNPs solution. That was to say, isoelectric point of gelatin was 9.6 and isoelectric point of gelatin-AgNPs was 9.7. The increasing of protein isoelectric point indicated more basic amino acids remaining in gelatin-AgNPs. It was evidence that AgNPs were mainly absorbed by gelatin acid amino acids.

\section{Influence of Temperature on the Interaction between Gelatin and AgNPs}

Fluorescence Quenching Type Classification

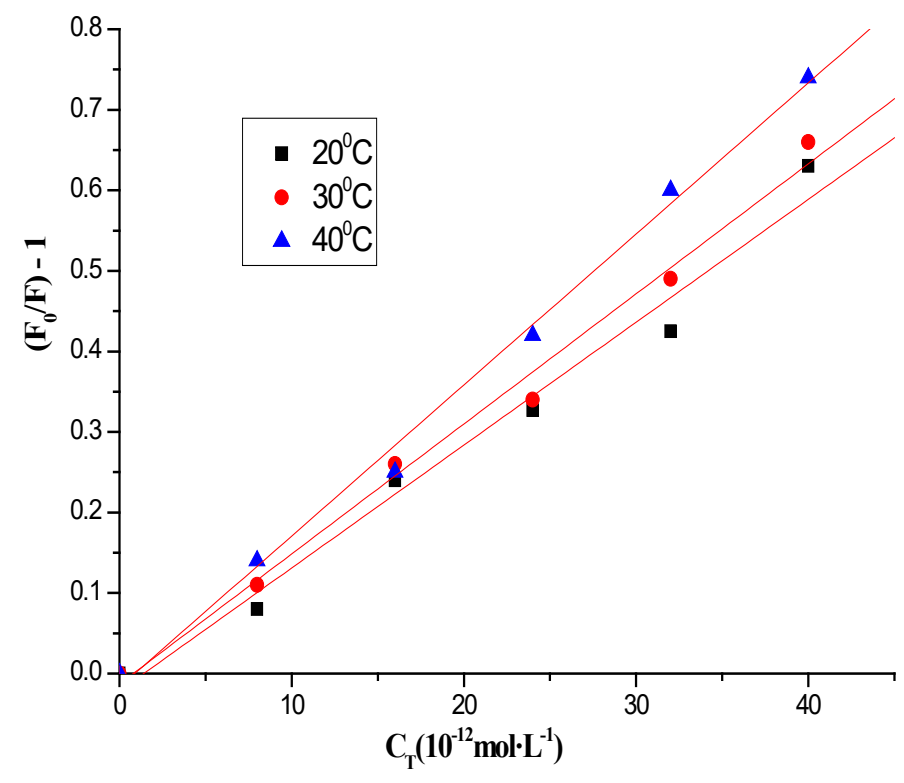

Figure 6. Stern-Volmer relationship between the concentration of AgNPs and fluorescence intensity of gelatin at different temperature 
Stern-Volmer relationship between the concentration of AgNPs and fluorescence intensity of gelatin at different temperature was shown in Figure 6 , where $F_{0}$ and $F$ were the fluorescence intensities of gelatin in absence and presence of AgNPs separately, and $C_{t}$ was the concentration of the AgNPs in the mixed solution. As shown in Figure 6, more significant fluorescence quenching generated under higher temperature and the slope of each line increased with temperature ascending.

Fluorescence quenching could be divided in to dynamic quenching and static quenching. For both quenching processes, the fluorescence intensity is proportional to the fluorescence quencher concentration. The linear SternVolmer equation was [30]:

$\mathrm{F}_{0} / \mathrm{F}=1+\mathrm{K}_{\mathrm{q}} \tau_{0} \mathrm{C}_{\mathrm{t}}=1+\mathrm{K}_{\mathrm{sv}} \mathrm{C}_{\mathrm{t}}$

where $\mathrm{K}_{\mathrm{sv}}$ was the quenching constant and equaled to $K_{q} \tau_{0}$, in which $K_{q}$ was the biomolecular quenching rate constant and $\tau_{0}$ was the average lifetime of the fluorescent molecules without addition of a quencher. Since dynamic fluorescence depended on diffusion rate, and diffusion rate increased with temperature rising, meaning constant of dynamic quenching $\left(\mathrm{K}_{\mathrm{sv}}\right)$ enlarging with temperature increasing. Therefore, it could conclude the fluorescence quenching of gelatin interacted with AgNPs was dynamic quenching.

\section{Binding Constant and Number of Binding Sites Analysis}

The binding constant and the number of binding sites between gelatin and AgNPs could be calculated based on fluorescence intensity changing under different temperature. If there were equal and independent binding sites (n) between gelatin (G) and the fluorescence quenchers AgNPs (S), the quenching reaction between gelatin and AgNPs was as follows:

$n G+S=G_{n} S$

The binding constant $\mathrm{K}_{\mathrm{A}}$ was:

$\mathrm{K}_{\mathrm{A}}=\mathrm{C}_{\mathrm{GnS}} / \mathrm{C}_{\mathrm{S}}{ }^{\mathrm{n}} \cdot \mathrm{C}_{\mathrm{G}}$

where $\mathrm{C}_{\mathrm{s}}=$ concentration of fluorescence quencher (AgNPs);

$\mathrm{C}_{\mathrm{G}}=$ concentration of gelatin;

$\mathrm{C}_{\mathrm{GnS}}=$ concentration of $\mathrm{G}_{\mathrm{n}} \mathrm{S}$.

The fluorescent substance concentration $\left(C_{G 0}\right)$ was:

$\mathrm{C}_{\mathrm{GO}}=\mathrm{C}_{\mathrm{SnG}}+\mathrm{C}_{\mathrm{G}}$

Then,

$\mathrm{K}_{\mathrm{A}}=\mathrm{C}_{\mathrm{G} 0}-\mathrm{C}_{\mathrm{G}} / \mathrm{C}_{\mathrm{S}}{ }^{\mathrm{n}} \cdot \mathrm{C}_{\mathrm{G}}$

During the static fluorescence quenching process, the fluorescence intensity is proportional to the concentration of the free fluorescent substance, and the equation is as follows:

$\mathrm{C}_{\mathrm{G}} / \mathrm{C}_{\mathrm{GO}}=\mathrm{F} / \mathrm{F}_{0}$

According to (4) and (5),

$\lg (\mathrm{F} 0-\mathrm{F}) / \mathrm{F}=\lg \mathrm{K}_{\mathrm{A}}+\mathrm{nlg}_{\mathrm{S}}$

The binding constant $\left(\mathrm{K}_{\mathrm{A}}\right)$ and the number of reaction sites ( $n$ ) in equation (6) could be calculated from the intercept $\left(\operatorname{lgK}_{A}\right)$ and the slope in Figure 7, and the results were shown in Table 1. 


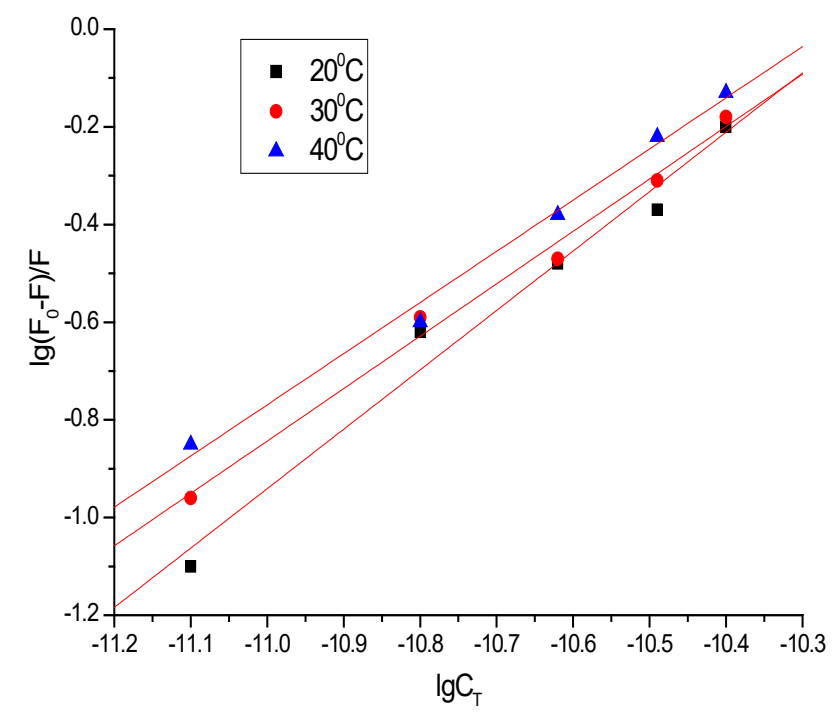

Figure 7. Relationship between the fluorescence intensity of gelatin and the different concentration of AgNPs

Table 1: Number of interaction sites $(n)$ and interaction constants $\left(K_{A}\right)$ at different temperatures

\begin{tabular}{ccc}
\hline $\mathrm{T}\left({ }^{\circ} \mathrm{C}\right)$ & $\mathrm{K}_{\mathrm{A}}$ & $\mathrm{n}$ \\
\hline 20 & $2.75 \times 10^{11}$ & 1.22 \\
30 & $9.15 \times 10^{10}$ & 1.07 \\
40 & $5.7 \times 10^{10}$ & 1.05 \\
\hline
\end{tabular}

In Table 1, binding ratio of gelatin and AgNPs at different temperatures was about 1:1 and decreased with temperature. The relationship between reaction constant and temperature was negative. $\mathrm{K}_{\mathrm{A}}$ decreased from $2.75 \times 10^{11}$ at $20^{\circ} \mathrm{C}$ to $5.7 \times 10^{10}$ at $40^{\circ} \mathrm{C}$, indicating the interaction between gelatin and AgNPs was diffusive encounters.

Thermodynamic Functions Calculation

The $\Delta \mathrm{H}_{\mathrm{m}}{ }^{\ominus}, \Delta \mathrm{G}_{\mathrm{m}}{ }^{\ominus}$ and $\Delta \mathrm{S}_{\mathrm{m}}{ }^{\ominus}$ could demonstrate the main type of the reaction between gelatin and AgNPs based on Van't Hoff equations.

$\Delta \mathrm{G}_{\mathrm{m}}{ }^{\ominus}=\Delta \mathrm{H}_{\mathrm{m}}{ }^{\ominus}-\mathrm{T} \Delta \mathrm{S}_{\mathrm{m}}{ }^{\ominus}$

$\Delta G_{m}{ }^{\ominus}=-R T \ln K$ $\ln \left[\mathrm{K}_{\mathrm{T} 2} / \mathrm{K}_{\mathrm{T} 1}\right]=\Delta \mathrm{H}_{\mathrm{m}}{ }^{\ominus}\left(\mathrm{T}_{2}-\mathrm{T}_{1}\right) / \mathrm{RT}_{1} \mathrm{~T}_{2}$

where $T_{1}, T_{2}$ and $T$ were the temperatures of the reaction, $\Delta \mathrm{H}_{\mathrm{m}}{ }^{\ominus}$ was considered as a constant when the temperature slightly changes. Combining the reaction constants $\left(\mathrm{K}_{\mathrm{A}}\right.$ ) from Table $1, \Delta \mathrm{H}_{\mathrm{m}}{ }^{\ominus}, \Delta \mathrm{G}_{\mathrm{m}}{ }^{\ominus}$ and $\Delta \mathrm{S}_{\mathrm{m}}{ }^{\ominus}$ can be calculated by equations (7), (8) and (9), separately. The results were shown in Table 2.

Table 2: Thermodynamic functions of gelatin with AgNPs at different temperatures

\begin{tabular}{cccc}
\hline $\mathrm{T}(\mathrm{K})$ & $\Delta \mathrm{H}_{\mathrm{m}}{ }^{\ominus}(\mathrm{kJ} / \mathrm{mol})$ & $\Delta \mathrm{G}_{\mathrm{m}}{ }^{\ominus}(\mathrm{kJ} / \mathrm{mol})$ & $\Delta \mathrm{S}_{\mathrm{m}}{ }^{\ominus}(\mathrm{J} / \mathrm{mol} \cdot \mathrm{K})$ \\
\hline 293 & -37.3 & -69.7 & 100.6 \\
303 & -37.3 & -63.5 & 86.5 \\
313 & -37.3 & -64.4 & 86.6 \\
\hline
\end{tabular}


In Table 2, $\Delta \mathrm{G}_{\mathrm{m}}{ }^{\ominus}$ at each temperature was below zero, showing that the reaction between gelatin and AgNPs was spontaneous. According to the thermodynamic regulation

Influence of AgNPs on Gelatin Structure of reaction types [31], the main type of reaction between gelatin and AgNPs was electrostatic interaction.

FT-IR Results

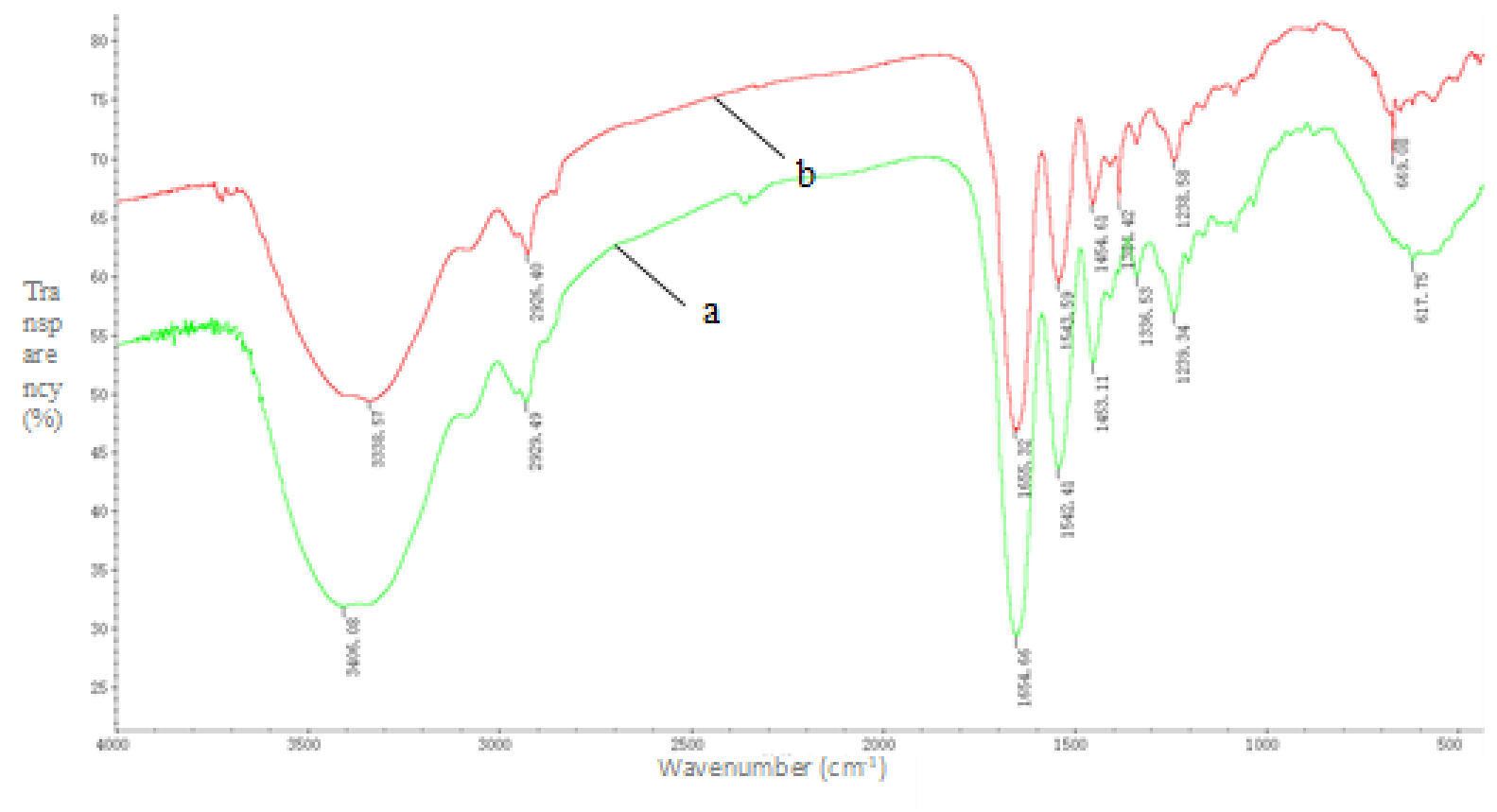

Figure 8. FT-IR image of gelatin interacted with AgNPs (a: pure gelatin, b: after)

The FT-IR image of gelatin interacted with AgNPs was shown in Figure 8. The wavenumber of gelatin-AgNPs at around $1650 \mathrm{~cm}^{-1}$ was almost the same as pure gelatin, indicating AgNPs did not impact protein structure during interaction, and the conformation of gelatin was still $\alpha$ helix. However, new peaks emerged at wavenumber at around $1380 \mathrm{~cm}^{-1}$ and $669 \mathrm{~cm}^{-1}$ after gelatin interacted with AgNPs might be the results that AgNPs reacted with oxygen atom in gelatin through electrostatic interaction.

\section{CONCLUSIONS}

When gelatin was blended with nanosilver particle, an interaction was generated but the interaction was weak and no chemical bond was formed. The main type of reaction between gelatin and AgNPs was mainly electrostatic interaction and mainly generated by gelatin acid amino acid. Gelatin could not affect the particle size and distribution of nano-silver, however there was dynamic fluorescence quenching of gelatin under nano-silver particle induced. The longer time and lower $\mathrm{pH}$ were beneficial for the interaction between gelatin and nano-silver particle while the interaction balanced after $60 \mathrm{~min}$ and $\mathrm{pH} 3.0$ resulted in the most drastic interaction. Moreover, nano-silver would not impair gelatin structure during the interaction process. The results in this work might be a foundation and reference for applying nanosilver in antibacterial leather producing.

\section{Acknowledgements}

The authors wish to thank the financial support of Scientific Research Project of Guangdong Administration for Market Regulation (2020ZZ15). 


\section{REFERENCES}

1. Raji, P., Samrot, A.V., Bhavya, K.S., Sharan, M., Sri Priya, S., Paulraj P., Greener approach for leather tanning using less chrome with plant tannins and tannins mediated nanoparticles, J Clust Sci, 2019, 30, 1533-1543, https://doi. org/10.1007/s10876-019-01597-6.

2. Xiang, J., Ma, L., Su, H., Xiong, J.J., Li, K.L., Xia, Q.F., Liu, G.Y., Layer-by-layer assembly of antibacterial composite coating for leather with cross-link enhanced durability against laundry and abrasion, Appl Surf Sci, 2018, 458, 978-987, https://doi.org/10.1016/j. apsusc.2018.07.165.

3. Velmurugan, P., Vedhanayakisri, K.A., Park, Y.J., Jin, J.S., Byung, T.O., Use of aronia melanocarpa fruit dye combined with silver nanoparticles to dye fabrics and leather and assessment of its antibacterial potential against skin bacteria, Fibers Polym, 2019, 20, 302-311, https://doi.org/10.1007/s12221019-8875-2.

4. Xia, Q.F., Yang, L., Hu, K., Li, K.L., Xiang, J., Liu, G.Y., Wang Y.B., Chromium cross-linking based immobilization of silver nanoparticle coating on leather surface with broad-spectrum antimicrobial activity and durability, ACS Appl Mater Interfaces, 2019, 11, 2352-2363, https://doi.org/10.1021/acsami.8b17061.

5. Ara, K., Hama, M., Akiba, S., Koike, K., Okisaka, K., Hagura, T., Kamiya, T., Tomita, F., Foot odor due to microbial metabolism and its control, Can J Microbiol, 2006, 52, 357-364, https:// doi.org/10.1139/w05-130.

6. Hayat, S., Muzammil, S., Rasool, M.H., Zonaira Nisar, Z., Jamil, S., In vitro Antibiofilm and anti-adhesion effects of magnesium oxide nanoparticles against antibiotic resistant bacteria, Microbiol Immunol, 2018, 62, 211- 220, https://doi.org/10.1111/13480421.12580 .

7. Velmurugan, P., Lee, S.M., Cho, M., Park, J.H., Seo, S.K., Myung, H., Bang, K.S., Byung, T.O., Antibacterial activity of silver nanoparticlecoated fabric and leather against odor and skin infection causing bacteria, Appl Microbiol Biotechnol, 2014, 98, 8179-8189, https://doi. org/10.1007/s00253-014-5945-7.

8. Kaygusuz, M., Application of antimicrobial nano-materials on leather: a review, J Soc Leath Tech Ch, 2017, 101, 173-178.
9. Gu, H.B., Zhao, L., Ma, J., Yang, Y.J., Zhao, C.Q., Chen, W.Y., Control of microorganisms on tanned leather: from fungicide to antimicrobial function leather, J Am Leather Chem Assoc, 2016, 111, 69-87.

10. Qiao, Y., Ma, F., Liu, C., Zhou, B., Wei, Q.L., Li, W.L., Zhong, D.N., Li, Y.Y., Zhou, M., Nearinfrared laser-excited nanoparticles to eradicate multidrug-resistant bacteria and promote wound healing, ACS Appl Mater Interfaces, 2018, 10, 193-206, 2018, https:// doi.org/10.1021/acsami.7b15251.

11. Nogueira, S.S., de Araujo-Nobre, A.R., Mafud, A.C., Guimarães, M.A., Alves, M.M.M., Plácido, A., Carvalho, F.A.A., Arcanjo, D.D.R., Mascarenhas, Y., Costa, F.G., Albuquerque, P., Eaton, P., de Almeida Leite, J.R.de S., da Silva, D.A., Cardoso, V.S., Silver nanoparticle stabilized by hydrolyzed collagen and natural polymers: synthesis, characterization and antibacterial-antifungal evaluation, Int J Biol Macromol, 2019, 135, 808-814, https://doi. org/10.1016/j.ijbiomac.2019.05.214.

12. Liu, G.Y., Li, K.J., Luo, Q.Q., Wang, H.B., Zhang, Z.C., PEGylated chitosan protected silver nanoparticles as water-borne coating for leather with antibacterial property, J Colloid Interface Sci, 2017, 490, 642-651, https://doi. org/10.1016/j.jcis.2016.11.103.

13. Velmurugan, P., Shim, J., Kim, H., Lim, L.M., Kim, S.A., Seo, Y.S., Kim, J.W., Kim, K., Byung, T.O., Bio-functionalization of cotton, silk, and leather using different in-situ silver nanoparticle synthesis modules, and their antibacterial properties, Res Chem Intermed, 2020, 46, 9991015, https://doi.org/10.1007/s11164-0162481-3.

14. Yang, W.T., Li, H., Gong, Y., Chen, W.Y., Gaidau, C., Preparation of silver nanoparticles of enhanced antibacterial effect with benzalkonium bromide, J Optoelectron Adv Mater, 2011, 13, 661-665.

15. Yang, W.T., Wang, X., Gong, Y., Li, H., Chen, W.Y., Gaidau, C., Preparation of antibacterial sheepskin with silver nanoparticles, potential use as a mattress for pressure ulcer prevention, J Am Leather Chem Assoc, 2012, 107, 85-92.

16. Xia, Y., Chen, W.Y., Zou, Y.K., The anti-microbial property of bovine hide sleeping mat leather, Leather Science and Engineering, 2012, 22, 2, 55-58. 
17. Tang, Q.Y., Yang, Y., Zhang, J.W., Chen, W.Y., Application of nano silver composite antibacterial agent in shoe lining leather, China Leather, 2014, 43, 11, 11-13, 18.

18. Yang, W.T., Teng, B., Han, Y., Han, Y., Chen, W.Y., Gaidau, C., Interaction between keratin and silver nanoparticles: investigation by spectrofluorimetry, J Optoelectron Adv Mater, 2014, 16, 1159-1164.

19. Gaidau, C., Giurginca, M., Dragomir, T., Petica, A., Chen, W.Y., Study of collagen and leather functionalization by using metallic nanoparticles, J Optoelectron Adv Mater, 2010, 12, 2157-2163.

20. Gaidau, C., Petica, A., Micutz, M., Danciu, M., Vladkova T., Progresses in treatment of collagen and keratin-based materials with silver nanoparticle, Cent Eur J Chem, 2013, 11, 901-911, https://doi.org/10.2478/s11532013-0224-5.

21. Liu, W.T., Li, G.Y., Non-isothermal kinetic analysis of the thermal denaturation of type I collagen in solution using isoconversional and multivariate non-linear regression methods, Polym Degrad Stab, 2010, 95, 2233-2240, https://doi.org/10.1016/j. polymdegradstab.2010.09.012.

22. Cao, S.M., Wang, Y., Xing, L.J., Zhang, W.G., Zhou, G.H., Structure and physical properties of gelatin from bovine bone collagen influenced by acid pretreatment and pepsin, Food Bioprod Process, 2020, 121, 213-223, https://doi.org/10.1016/j.fbp.2020.03.001.

23. Aswana, D.L., Roselin, R.B., Sankar, V., Formulation, characterization and antibacterial activity evaluation of collagen based silver nanoparticle, Int J Pharm Sci Res, 2020, 11, 1735-1739.

24. Lavanya, K., Kalaimurugan, D., Shivakumar, M.S., Venkatesan, S., Gelatin stabilized silver nanoparticle provides higher antimicrobial efficiency as against chemically synthesized silver nanoparticle, J Clust Sci, 2019, 31, 265275, https://doi.org/10.1007/s10876-01901644-2.

25. Baukum, J., Pranjan, J., Kaolaor, A., Chuysinuan, P., Suwantong, O., Supaphol, P., The potential use of cross-linked alginate/gelatin hydrogels containing silver nanoparticles for wound dressing applications, Polym Bull, 2020, 77, 2679-2695, https://doi.org/10.1007/s00289019-02873-1.
26. Pham, T.N., Jiang, Y.S., Su, C.F., Jan, J.S., In situ formation of silver nanoparticles-contained gelatin-PEG-dopamine hydrogels via enzymatic cross-linking reaction for improved antibacterial activities, Int J Biol Macromol, 2020, 146, 1050-1059.

27. Zhang, J.W., Wang, Y., Wen, Y.H., Sun, H.B., Huang Y.K., Chen, W.Y., Influence of environmental factors on the stability of nano-silver colloid system, Fine Chemicals, 2021, 38, 91-96.

28. Zhang, Z.Q., Patel, R.C., Kothari, R., Johnson, C.P., Friberg, S.E., Aikens, P.A., Stable silver clusters and nanoparticles pre-pared in polyacrylate and inverse micellar solutions, $J$ Phys Chem B, 2000, 104, 1176-1182, https:// doi.org/10.1021/jp991569t.

29. Yang, H., Xu, S.C., Shen, L.R., Liu, W.T., Li, G.Y., Changes in aggregation behavior of collagen molecules in solution with varying concentrations of acetic acid, Int J Biol Macromol, 2016, 92, 581-586, https://doi. org/10.1016/j.ijbiomac.2016.07.080.

30. Amao, Y., Asai, K., Okura, I., Oxygen sensing based on lifetime of photoexcited triplet state of platinum porphyrin-polystyrene film using time-resolved spectroscopy, J Porphyr Phthalocyanines, 2000, 4, 292299, https://doi.org/10.1002/(SICI)10991409 ( $200004 / 05) 4: 3 \% 3 C 292$ : :AID JPP216\%3E3.0.CO;2-W.

31. Ross, P.D., Subramanian, S., Thermodynamics of protein association reactions-forces contributing to stability, Biochemistry, 1981, 20, 3096-3102, https://doi.org/10.1021/ bi00514a017.

(C) 2021 by the author(s). Published by INCDTPICPI, Bucharest, RO. This is an open access article distributed under the terms and conditions of the Creative Commons Attribution license (http:// creativecommons.org/licenses/by/4.0/). 